VOX PATRUM 21 (2001) t. 40-41

\author{
Alicja STĘPNIEWSKA \\ (Lublin, KUL)
}

\title{
MARYJA W TWÓRCZOŚCI GRZEGORZA Z NAREKU
}

W chrześcijaństwie niemal od 20 wieków Maryja jako Matka Zbawiciela otaczana jest czcią wiernych i zajmuje w ich sercach miejsce szczególne. Kiedy bowiem ogarniemy myślą wznoszone od stuleci liczne sanktuaria maryjne szeroko rozsiane po całym świecie, wsłuchamy się w melodię pieśni maryjnych, wzrok swój zatrzymamy na jej wizerunku czy to w formie obrazu oddanym pędzlem wytrawną ręką mistrza lub nieznanego malarza, czy wykutym w kamieniu bądź wyrzeźbionym w drewnie, w ciszy serca zgłębimy piękno poezji maryjnej - to czyż nie jest to żywe świadectwo obecności Bogurodzicy w naszym życiu i nie stanowi odpowiedzi na prorocze słowa, które padły z ust Maryi w Ain-Karim: „Błogosławić mnie będą odtąd wszystkie pokolenia” (Łk 1, 48). W miarę przyjmowania chrztu przez kolejne narody kult maryjny rozszerzał się i wzbogacał o coraz to nowe treści w zależności od obyczajów, a także uwarunkowań kulturowych i geograficznych danego narodu.

Świat chrześcijański obchodzi w tym roku 1700-letnią rocznicę chrztu Armenii. Nie sposób tu nie przypomnieć św. Grzegorza z Nareku (Grigor Narekatsi), poety, mistyka, komentatora Pisma św., zwanego „Pindarem armeńskim", o którym papież Jan Paweł II w encyklice Redemptoris Mater napisał, iż „w swym hymnie pochwalnym ku czci Theotókos..., w uniesieniu poetyckim zgłębia różne aspekty tajemnicy Wcielenia, a każdy z nich pomaga mu opiewać i wysławiać niezwykłą godność i wspaniałą piękność Maryi Dziewicy, Matki Słowa Wcielonego"1.

${ }^{1}$ Redemptoris Mater 31, wersja polska, Watykan 1987, 66; Jan Paweł II o Grzegorzu z Nareku wspomniał również podczas południowej modlitwy na Anioł Pański w niedzielę 18 II 2001 roku, tuż po jubileuszowej liturgii w rycie ormiańskim w Bazylice św. Piotra, odprawianej razem z patriarchą Cylicji Nersesem Bedrosem XIX z okazji 1700-lecia chrztu Armenii, gdy powiedział na zakończenie: „Powierzamy te życzenia Maryi Najświętszej, którą nasi bracia armeńscy czczą z głęboką pobożnością. Ich liturgia ma charakter wybitnie maryjny. Oni Ją nazywają Astrazazin - Matką Boga i zwracają się do Niej z tytułem Królowej Armenii. Jednym z głównych piewców Madonny jest wielki Doktor Kościoła armeńskiego św. Grzegorz z Nareku. Niech Święta Dziewica ochrania zawsze umiłowany naród armeński i wprowadzi go w stan odnowionej nadziei i pomyślności" (OsRom 141 (2001) nr 41 z 19-20 lutego, s. 9). 
O życiu Grzegorza zachowało się niewiele informacji, które czerpiemy zarówno z jego własnych wypowiedzi zamieszczanych w twórczości, z kolofonów pozostawianych przez kopistów jego pism, z armeńskiego synaksarium wspominającego go pod dniem 27 lutego, jak i świadectw historyków Kościoła armeńskiego, tworzących z czasem legendę jego życia ${ }^{2}$.

Urodzil się najprawdopodobniej ok. 944 (według innych w 951) r. w miejscowości Narek. Na chrzcie, jak sam wspomina, otrzymał imię Grigor (= arm. „Czujny”, „Baczny”) ${ }^{3}$. W pierwszych latach życia stracił matkę, a kiedy miał 5-6 lat został oddany przez ojca Chosroesa (zwanego później Wielkim) wraz ze starszym bratem Janem ${ }^{4}$ i bratem Izaakiem do leżącego nieopodal monasteru, w pobliżu jeziora Wan. Monaster był już wówczas znaczącym ośrodkiem kulturalnym, znanym $z$ prowadzonych tam na wysokim poziomie studiów literackich i działających sprawnie skryptoriów ${ }^{5}$. Swą świetność w dużej mierze zawdzięczał przełożonemu klasztoru wybitnemu uczonemu Ananiaszowi z Nare-

${ }^{2}$ O Grzegorzu z Nareku por.: Le Synaxaire Arménien de Ter Israel, ed. D.G. Bayan, PO 21, 100-102; F. Nève, L'Arménie chrétienne et sa littérature, Louvain 1886, 256-267; A. Tchobanian, Grégoire de Narek, „Mercure de France” 36 (1900) 369-405; E. Słuszkiewicz, Literatura armeńska, w: Wielka literatura powszechna, red. S. Lam, t. 1, Warszawa 1930, 441-442; D. Ghazarian, L'Anachorète oriental et Narek, Jérusalem 1937; R. Rakoupian, Grégoire de Narek, New York 1939; M. Abéghian, Histoire de la littérature arménienne, t. 1, Érévan 1944, 511-569; C. Kibarian, Gregorio di Narek poeta, „Bazmaveb” 108 (1950) 245-252; H. Thorossian, Histoire de la littérature arménienne des origines jusqu'à nos jours, Paris 1951, 118-120; K. Sarafian, Grégoire de Narek et son livre de prières „Narek”, California 1951; L.A. Marcel, Millenaire de Grégoire de Narek, Marseille 1951; tenże, Grégoire de Narek et l'ancienne poesie arménienne, Paris 1953; M. Mékérian, Grégoire de Narek, Érévan 1955; A. Mékhitarian, Grégoire de Narek, Érévan 1957; J. Kéchichian, Introduction, w: Grégoire de Narek, Le livre de prières, trad. franc., SCh 78, Paris 1961, 3148; S.J. Voicu, Patristica nella letteratura armena ( $V$-X sec.), w: Complimenti interdisciplinari di patrologia, a cura di A. Quacquarelli, Roma 1989,693; A. Mandalian, Wstęp, w: Grzegorz z Nareku, Księga śpiewów żałobliwych, tłum. A. Mandalian i inni, Warszawa 1990, 30-62; J.P. Mahé, Kościót armeński w latach 611-1066, w: D. Dagron - Ch. Hannick - J. Kłoczowski i inni, Biskupi, mnisi i cesarze 610-1054, tłum. G. Majcher (= Historia chrześcijaństwa, t. IV), Warszawa 1999, 427-428; słowniki: P. Ananian, BS VII 192-194; M. van Esbroeck, LThK ${ }^{2}$ IV 1209, LThK $^{3}$ IV 1004 K. Gębura, EK VI 312; J. Karst, DThC XI 24-26; J. Kéchichian, DSp VI 927-932; C. Kibarian, ECat VI 1088; A. Salaville, Catholicisme V 255; DHGE XXII 14.

${ }^{3}$ Por. Księga śpiewów żałobliwych. Słowo 72, tłum. A. Mandalian, Warszawa 1990, 380: „Na chrzcie świętym nazwano mnie «Czujnym»... W dniu, gdym składał śluby - «Baczącym»".

${ }^{4}$ Nota ku upamiętnieniu ułożenia tej Księgi, tamże, 438: „Przy współudziale świętego brata mego Jana / Mnicha wielce sławnego klasztoru Nareckiego / Z którym nie jeno z ciała będąc spokrewniony, / Ale z jedności duszy, myśli i uczynku./ Gdyż żyliśmy obaj jak ludzie o jednej pospólnej twarzy, / Śledząc dwoma parami oczu / Tę samą ścieżkę ducha, / Podjąłem się prac nad tą Księgą".

5 Por. Y. Derdérian, Narek dans la littérature arménienne, Jérusalem 1947; H. Oskian, Les couvents de Vaspourakan-Van, Vienne 1940; H. T'amrazyan, L'École de Narek, Érévan 1999; A. Mandalian, Wstęp, dz. cyt., s. 32-34. 
ku, stryjowi jego zmarłej matki, autorowi m.in. Księgi spowiednej i traktatu matematycznego Objaśnienie liczb, w którym dociekał tajemniczego znaczenia liczb biblijnych. Odczuwało się tu wyraźnie wpływ kultury bizantyjskiej, ze szczególnym zamiłowaniem do nauki języka greckiego, ale z antychalcedońskimi tradycjami monofizyckimi.

Ojciec Grzegorza Chosroes, wolny już od żony i dzieci, został biskupem diecezji Anczewaczik (na Wschodzie tylko osoba bezżenna mogła być biskupem) i rozpoczął gorliwą działalność duszpastersko-naukową pisząc m.in. Wyjaśnienie modlitwy Mszy św. i Komentarz do Oficjum brewiarzowego ${ }^{6}$. Wkrótce jednak popadł w konflikt z katolikosem Ananiaszem z Moku, najprawdopodobniej za sympatie (wbrew narodowej tradycji) dla greckiej teologii prochalcedońskiej, za co po śmierci został nawet przez niego wyklęty ${ }^{7}$. Ta atmosfera konfliktów religijnych, podejrzeń o herezję i wyklęcie ojca, wpłynęły niewątpliwie na przywiązanego do niego Grzegorza i była jednym ze źródeł duchowych rozterek, odbijających się na jego życiu i twórczości.

W takim środowisku i okolicznościach żył i wzrastał św. Grzegorz. Prowadził życie pokorne i czyste, dzieląc czas między pracę i modlitwę. Gruntownie poznał język grecki, jego gramatykę, retorykę i wymowę, studiował gorliwie i kontemplował Pismo św., pogłębiał wiedzę z matematyki, medycyny, architektury, astronomii i nautyki ${ }^{8}$. Po przyjęciu święceń kapłańskich został nauczycielem, a potem wychowawcą mnichów, osiągając zaszczytną godność wardapeta (filozofa). Grzegorz dużo czytał, znał liczne tłumaczenia armeńskie pism Ojców greckich i syryjskich m.in. Ireneusza, Euzebiusza z Cezarei, Bazylego, Grzegorza z Nazjanzu, Grzegorza z Nyssy, Jana Chryzostoma, Cyryla Jerozolimskiego, Afrahata, Efrema, a także Ojców armeńskich - Mojżesza z Chorenu, Eznika z Kolb, Koriuna, Elizeusza Wardapeta, Jana Mandakuniego.

Ananiasz, człowiek ogromnej wiedzy i świętości, nazywany przez współczesnych „filozofem”, wprowadzał swego podopiecznego w dyscyplinę zakonną Bazylego Wielkiego i intensywne życie duchowe. Grzegorz wiele czasu spędzał na kontemplacji, czemu niewątpliwie sprzyjało piękno otaczającej przyrody nareckiej, zaś nieodparty jej urok wzbogacał wyobraźnię, a dziewicza potęga nieujarzmionej natury uwrażliwiała duszę przyszłego poety-mistyka. Już współcześni nazywali go „Świętym”, „Dobrym”, „Sprawiedliwym”, „Rabbim”, „Nauczycielem"9. To głębokie przeżywanie przyrody przez Grzegorza połączone z odbytymi studiami muzycznymi, które swym wysokim poziomem wyróżniało

${ }^{6}$ O Chosroesie i Ananiaszu oraz ich twórczości por. S.J. Voicu, Patristica nella letteratura armena, s. 692-693; Khosrow, Explication des prières de la Messe, Venise 1869; H. T'amrazyan, Anania Narekaci, sa vie, son oeuvre, Érévan 1986.

${ }^{7}$ Por. J. Mécérian, Préface, w: Grégoire de Narek, Le livre de prières, SCh 78, dz. cyt., s. 21-23; A. Mandalian, Wstęp, 30-31.

${ }^{8}$ Por. Księga śpiewów załobliwych. Stowa 25 i 43.

${ }^{9}$ Por. tamze, Stowo 72. 
monaster w Nareku, mogło wywrzeć duży wpływ na bogactwo jego twórczości zarówno w treści, jak i w formie. Jego pisma, zwłaszcza Śpiewy żałobliwe, pełne są cytatów i reminiscencji biblijnych, jak również poprawnych teologicznych formuł trynitarnych i chrystologicznych, poświadczających solidną znajomość podstawowych prawd wiary. Zmarł w opinii świętości, według tradycji armeńskiej ok. 1003 roku, zdaniem zaś uczonych współczesnych ok. 1010 roku w monasterze Narek, pochowany przy kościele świętej Santukty. Grób Grzegorza stał się wkrótce miejscem tłumnych pielgrzymek, gdyż jego relikwiom przypisywano moc czynienia cudów, zwłaszcza od kiedy bp Cylicji Nerses z Lampronu (1153-1198) nazwał go ,aniołem przyobleczonym w ciało”.

Grzegorz z Nareku pozostawił po sobie niemałą twórczość literacką ${ }^{10}$. Można ją najogólniej podzielić na kilka grup: 1. Hymny lub pieśni religijne (tagi), w liczbie 20, dzieło młodości, które choć nie miały charakteru liturgicznego, bo nie wchodziły w skład kanonów i nie podlegały zasadom obowiązującym przy tworzeniu szarakanów, przeznaczone były jako pieśni radosnego uwielbienia do śpiewania podczas nabożeństw w 12 głównych świętach kościelnych (np. na Boże Narodzenie, na Epifanię, na Zmartwychwstanie Pańskie, na Pięćdziesiątnicę) i kilku świętych (np. na święta Najświętszej Maryi Panny) ${ }^{11}$. Najpiękniejszymi są chyba wśród nich: „Pieśń na Zmartwychwstanie”, „Diamentowa róża"12 będąca pieśnią (tagiem) na dzień Wardawaru (Przemienienia) oraz „Pieśń o Teofanii”. 2. Komentarz do Pieśni nad Pieśniami, napisany w 977 roku na zamówienie księcia (972-982) Gurgena-Haczika, późniejszego króla (9831003) Waspurakanu ${ }^{13}$. Autor wyjaśnia w nim głęboki mistyczny sens tej księgi biblijnej, oznaczający według niego w Starym Testamencie przymierze Jahwe z Izraelem, zaś w Nowym Testamencie - zaślubiny wcielonego Słowa Bożego z Kościołem. 3. Historia Krzyża św. z Aparank, w której Grzegorz w entuzjastycznym stylu opowiada o przeniesieniu relikwii drzewa Krzyża św. z Konstan-

${ }^{10}$ Wydali ją po raz pierwszy w całości w 1789, 1827 i w 1840 r. OO. Mechitarzyści w Wenecji w opracowaniu Gabriela Avédikiana: S. Grégoire de Narek, Oeuvres complètes, rec. G. Avédikian, Venise 1840 , ss.535. W przekładzie polskim tylko w wyborze: Stara poezja armeniska. Wybral, wstępem i przypisami opatrzył A. Mandalian, Warszawa 1970, 57-64; Muza chrześcijańska, t. 1: Poezja armeńska, syryjska i etiopska, OŻ VI, red. M. Starowieyski, Kraków 1985, 41-78; Grzegorz z Nareku, Księga śpiewów żałobliwych, przekład zbiorowy, wybór, wstęp i przypisy A. Mandalian, Warszawa 1990, ss. 454. Jej krótką charakterystykę zob. I. Kéchichian, Introduction, w: Grégoire de Narek, Le livre de prières, s. 36-39; A. Mandalian, Wstęp, w: Grzegorz z Nareku, Księga śpiewów zatobliwych, s. 36-62.

11 Por. U. Faldati, Liriche mistiche di S. Gregorio di Nareg, „Bessarione” 38 (1922) 144-148; A. Keskerian, Grigor Narekatsi. Pesni i Gandzy, Érévan 1981; rec. REArm 16 (1982) 462-467; Grigor Narekaci, Odes et hymnes, ed. A. K'yoskeryan, Érévan 1981 (po armeńsku); J.P. Mahé, Grégoire de Narek, poète liturgique, REArm NS 16 (1982) 464-467.

${ }_{12}$ Ich polski przekład w: Muza chrześcijańska, t. 1, 41-44.

13 Por. Gregory of Narek's Commentary of the Song of Songs, trad. R.W. Thomson, JThS 34 (1983) 453-490; Commentario sul Cantico dei Cantici di Gregorio di Narek, trad. V. Mistrih, ,,Studia orientalia christiana collectanea” 12 (1967) 465-534, 13 (1968-1969) 199-261; zob. niżej n. 21. 
tynopola do Armenii (983), umieszczonych najpierw w kościele św. Jana Chrzciciela, a potem w kościele Najśw. Maryi Panny, oraz związane z tym faktem dwa inne utwory napisane ok. 984 r. na zamówienie bpa Stefanosa z Mok - Panegiryk ku czci Krzyża św. złożony z 46 paragrafów, z których 9-44 rozpoczynają się od poszczególnych kolejnych liter alfabetu armeńskiego, oraz Panegiryk ku czci Matki Bożej, podzielony na 24 paragrafy, który swą formą nawiązuje do bizantyjskiego akatystu ${ }^{14}$, a konkretnie do arcydzieła bizantyjskiej poezji liturgicznej - słynnego Akatystu ku czci Bogurodzicy ${ }^{15}$, przypisywanego Romanowi Melodosowi (VI w.). W panegiryku tym Grzegorz objawił swój geniusz poetycki oraz swoje gorące uczucia żywione wobec Bogurodzicy. Do panegiryku dołączona jest skierowana do Maryi rytmizowana modlitwa, której pierwsze litery sześciu strof tworzą akrostych „Grigor" - imię autora. 4. Trzy rytmizowane Mowy w formie modlitwy litanijnej, nazwane „Kants” (tzn. skarby): o Duchu Świętym, o Kościele i o Krzyżu świętym, ułożone za panowania króla GurgenaHaczika (983-1003) i niejako podpisane przez autora, bowiem pierwsze litery strof każdej z nich układają się w akrostych „Grigori erg” (hymn Grzegorza). Dostarczają one informacji o ówczesnym podziale społeczeństwa armeńskiego: na rodzinę królewską, duchowieństwo, szlachtę, wojsko i lud. 5. Panegiryk ku czci Apostołów i 70 uczniów, podzielony na 23 paragrafy, a ułożony najprawdopodobniej w latach 984-1002, ponieważ czyni do niego aluzję w 82 Słowie śpiewów żałobliwych ${ }^{16}$, a więc współczesny panegirykom ku czci Krzyża św. i Matki Bożej. W utworze tym wychwala godność Apostołów, wyższą nad innymi świętymi, gdyż na ziemi żyli w zażyłości z Chrystusem i ponieśli Jego Dobrą nowinę wszystkim narodom aż na krańce świata; natomiast 70 uczniów uczestniczyło w tej ewangelizacji, a ich imiona są zapisane w niebie. 6. Panegiryk ku czci św. Jakuba z Nisibis, napisany w tym samym czasie, co poprzedni ku czci Apostołów, najprawdopodobniej z okazji jakiejś rocznicy lub przeniesienia relikwii bardzo lubianego przez Armeńczyków biskupa niedalekiej Nisibis, św. Jakuba († 338), uczestnika Soboru Nicejskiego (325) i współczesnego św. Grzegorzowi Oświecicielowi; autor w długiej mowie, złożonej aż z 30 paragrafów, wychwala za pomocą różnych porównań życie Biskupa oraz jego cuda i zasługi w obronie Kościoła. 7. Księga śpiewów żałobliwych - to najważniejsze

${ }^{14}$ Gregorio di Narek, Discorso panegirico alla Beatissima Vergine Maria, trad. P.A. Tiroyan, Venezia S. Lazzaro 1904; Le Panégiryque de la sainte Mère de Dieu de Grigor Narekaci, trad. Th. Dasnabédian, Antelias 1995 (przekład francuski i obszerny komentarz).

${ }^{15}$ Por. Muza chrześcijańska, t. 3: Poezja grecka od II do XV wieku, Kraków 1995, 194-208 (jako anonimowa); zob. też: Roman Piewca, Kontakion: Maryja pod krzyżem, SCh 128, 143-187, tłum. W. Kania, Teksty o Matce Bożej, t. 1: Ojcowie Kościoła greccy i syryjscy, Niepokalanów 1981, 110-118.

${ }^{16}$ Por. Księga spiewów żatobliwych. Stowo 82, s. 412: „Za wstawiennictwem Apostołów świętych/...Których wedle ich zasług i wedle możności/ Sławiłem ku chwale Twojej w innych swych modlitwach". 
dzieło Grzegorza ${ }^{17}$, które zapewniło mu pamięć i rozgłos, opublikowane na prośbę współbraci mnichów, jak można wnioskować z jego wskazówek ${ }^{18}$, w 1002 roku, po trzech latach pracy prowadzonej z pomocą brata Jana na wzór budowania katedry ${ }^{19}$. Księga składa się z 95 Słów (banów) o różnej długości, ujętych w formie pokornej i uniżonej rozmowy z Bogiem. Modlitwa ta, to nie tylko pokorne błagania, ale i pełne osobistych rozterek rozmyślania oparte na Biblii i tradycji patrystycznej, ukazujące przepaść między miłosiernym Bogiem a grzesznym upadłym człowiekiem. Grzegorz wzniósł się w tym dziele na szczyty twórczości poetyckiej, ono zaś samo stało się dla Armeńczyków najpopularniejszym po Biblii i Psalmach modlitewnikiem, który trzeba umieścić wśród głównych dzieł literackich ludzkości ${ }^{20}$.

Oprócz wyżej wymienionych pism, przypisywanych powszechnie ${ }^{21}$ Grzegorzowi z Nareku, do jego twórczości niektórzy badacze zaliczają jeszcze m.in. Rady o prawowitej wierze i cnotach ${ }^{22}$, Komentarz do 38 rozdziatu Księgi Hioba, lecz ich autorstwo jest bardzo wątpliwe ${ }^{23}$.

${ }^{17}$ Por. Oeuvres complètes, rec. G. Avédikian, Venise 1840, ss. 1-268; najnowsze wydanie tej księgi (tekst armeński i przekład w języku zachodnioarmeńskim) opracował ostatnio bp Trapizoni Garekin, Buenos Aires 1948, przedruk w wyd. Caravan Books w 1981 ze wstępem i bibliografią J.R. Russella. Przekład francuski: Grégoire de Narek, Le livre de prières. Introduction et traduction de l'arménien I. Kéchichian, SCh 78, Paris 1961; Grigor Narekac'i, Matean Otbergutean (Księga lamentacji), tekst krytyczny oprac. Xač‘atryan (Połos M.) i Łazinyan (Aršaluys A.), Érévan 1985 jest to najpełniejsze wydanie krytyczne po armeńsku; Grégoire de Narek, Tragédie Matean otbergut ean (Le Livre de Lamentation), introduction, traduction française et notes Annie et JeanPierre Mahé, CSCO 584, Subsidia 106, Lovanii 2000; przekład polski w dużym wyborze: Grzegorz z Nareku, Księga śpiewów żałobliwych. Wybór, wstęp i przekład większości A. Mandalian, Warszawa 1990; zob. tez A. Eazinyan, The Nature of Gregory of Narek's Book of Lamentation, REArm NS 18 (1984) 109-124

18 Por. Księga śpiewów żałobliwych. Nota ku upamiętnieniu ułożenia tej Księgi, 437: „Ku końcowi i po spełnieniu dziewiątego Jubileusza / U początków wstąpienia w dziesiąty, / Wedle rachuby czasu naszego plemienia Japheta, / W trzy lata po wkroczeniu / W obszary północne i wschodnie / Zwycięskiego i potężnego cesarza Romejczyków, Basileusa,".

19 Por. tamże 438: ,Jam to, ksiądz i zakonnik, Grzegorz, / Ostatni z poetów, / Najpośledniejszy z kapłanów, / Założył jej podwaliny, / Ułożył i nadał porządek, / Ozdobił i upiększył, / Pozbierał i zgromadził, / Spisal i ukazał; / A połączywszy jej części / W jedną piękną całość / Uczyniłem ową rzecz. użyteczną"; zob. też wyżej notę 4.

${ }^{20}$ Por. Ch. Renoux, Langue et littérature arméniennes, w: Christianismes Orientaux. Introduction à l'étude des langues et des littératures, préf. A. Guillaumont, Paris 1993, 151: „son Livre de lamentations qu'il faut placer au nombre des chefs d'ouvres littéraires de l'humanité".

${ }^{21}$ Grzegorzowe pochodzenie Komentarza do Pieśni nad Pieśniami, wydanego również oddzielnie w Wenecji w $1779 \mathrm{i}$ w $1827 \mathrm{r}$. pod jego imieniem, bywa dziś przez niektórych badaczy kwestionowane, por. C. Kibarian, Grégoire de Narek et le Commentaire du Cantique des cantiques, „Bazmaveb” 119 (1961) 1-10; J. Mécérian, Histoire et institutions de l'Église arménienne. Evolution nationale et doctrinale, Beyrouth 1965, 159-175.

${ }^{22}$ Wydane oddzielnie pod jego imieniem w Konstantynopolu w 1774 roku, a w wydaniu weneckim z $1840 \mathrm{r}$. na stronach 483-533.

${ }^{23}$ Por. I. Hausherr, Arménienne spiritualité, DSp I 870. 
Wśród bogatej, wyżej przedstawionej, twórczości Grzegorza nie mogło zabraknąć utworów o treści maryjnej ${ }^{24}$. Wymienić tu należy młodzieńczą Pieśn o Teofanii (O narodzeniu i objawieniu się Zbawiciela), zawierającą liczne wątki maryjne, Panegiryk ku czci Bogurodzicy oraz 80 Stowo z Księgi śpiewów załobliwych poświęcone w całości Maryi, a także drobne wzmianki maryjne w innych Stowach tej Księgi.

1. W Pieśni o Teofanii ${ }^{25}$ opisuje Grzegorz objawianie się ludziom Zbawiciela, w czym ważną rolę odegrała również Maryja. Starożytny rytuał armeński, zgodnie z tradycją Wschodu, łączy w tym samym dniu (6 stycznia) Święta Bożego Narodzenia i Epifanii oraz wspomnienie Chrztu Chrystusa: jest to potrójna teofania, jak to nierzadko przypominali Ojcowie Kościoła. W tych zaś trzech tajemnicach Syn i Jego dziewicza Matka byli ze sobą wewnętrznie zjednoczeni.

Poeta rozpoczyna swój utwór od opisu przyrody na wiosnę, kiedy maluje kwiat róży rozchylający swe płatki na liściach krzewu, zespalający się z kroplami rosy skrzącymi się w promieniach słońca. Podobnie postąpił Syn Boży, Blask chwały, Słońce miłości, który właśnie z miłości zstąpił w łono wybranej Dziewicy Maryi, łącząc się z nią w niewypowiedzianej tajemnicy. Dalej zastanawia się, kim jest ta Dziewica, godna tak wielkiej tajemnicy. Najpierw w sposób realistyczny przedstawia postać Maryi dostrzegając jej piękno kobiece. Mówi o oczach, o splotach włosów spływających wokół policzków, o ustach, piersiach, tunice i pasku, a nawet o stąpaniu lekkim i wdzięcznym. Potem wskazuje także na źródło, skąd wypływa jej piękność:

„Temu Królowi, temu nowo narodzonemu Zbawicielowi,

Temu, który cię tak przyozdobil, wieczna chwała"26.

Następnie słowami Pieśni nad Pieśniami opisuje Maryję, która stała się Oblubienicą niebieską oraz Matką, a dalej Króla narodzonego w Betlejem,

${ }^{24}$ Problemem mariologii Grzegorza z Nareku zajmowali się: J.M. Bover, Un notable mariólogo armeno, San Gregorio de Nareg, ,Revista española de teología” 1 (1941) 409-417; G. Amadouni, Il piu grande dottore mariano della Chiesa Armena - San Gregorio di Narek, w: Alma socia Christi, Roma 1952, V 2, 80-95; J. Mécérian, La Vierge Marie dans la littérature médiévale de l'Arménie. Grégoire de Narek et Nersès de Lampron, Beyrouth 1954; M. Tallon, Le culte de la Vierge Marie en Asie Mineure du I $I^{e r}$ au XV siècle, w: Maria, Paris 1956, IV 906-916; B. Levon Zekiyan, Il santo monaco Gregorio di Narek poeta del mistero della Madre di Dio, OsRom 127 (1987) nr 280 (23-24 XI); G.M. Roschini, Dizionario di Mariologia, Roma 1961, 197-198.

25 Tekst pieśni: Grégoire de Narek, Oeuvres complètes, Venise 1840, 472-475; Grigor Narekaci, Taler u ganjer (Ody i hymny), ed. A. K'yoskeryan, Érévan 1981, 111-115; por. J. Mécérian, La Vierge Marie dans la littérature médiévale de l'Arménie. Grégoire de Narek et Nersès de Lampron, Beyrouth 1954, 12-13.

${ }^{26}$ Teksty, oprócz Księgi pieśni żatobliwych, tłumaczone są z przekładów włoskiego lub francuskiego. 
adorowanego przez pasterzy i mędrców, Chrystusa błogosławionego przez wszystkich na wieki wieków.

Stając w obecności tego wielkiego misterium, misterium objawiającego się Ojca w Synu Narodzonym w ziemskim ciele, poeta idzie dalej i głosi wszystkim wokoło „dobrą nowinę”, powtarzając kilkakrotnie to wyrażenie:

„Przede wszystkim Maryi, Matce Pana, błogosławionej, podobnej do serafinów, stolicy cherubinów, najwyższej czystości zbliżonej do Trójcy, gwieździe świecącej na wysokościach, gdzie tysiąc tysięcy istot skrzy się i błyszczy w snopie twego światła; lecz ty mała i dyskretna ścieżko, ty prowadzisz ku drodze do Nieznanego. Dobra Nowina Tobie, Matko Pana, Dziewico Maryjo, Świątynio Słowa”.

Poeta przepełniony radością ogłasza z mocą „dobrą nowinę” kolejno domowi Adama, którego przekleństwo zostało w tym dniu zniesione, oraz patriarchom, prorokom i miastu Betlejem. Następnie przekazuje ją kwiatom:

„Dobra nowina kwiatom, które radosne rozkwitają na drzewach,

i które pięknem kolorów zwiastują owoce miłe dla oczu

i słodkie w smaku; dobra nowina wiązankom kwiatów

roztaczających woń radosną; pączki ich róż otwierają się

wdzięcznie, ich płatki promieniste rozpościerają się pośród

zieleni gęstych liści".

Podobnie Jan Chrzciciel, który ze swą matką obejmował i adorował Chrystusa, pełen uniesienia głosi na pustyni dobrą nowinę ,źródłom strumyków wody, które szemrząc i weseląc się, dopiero co wijące się wąskimi strużkami przez meandry piasku, a wnet zwiększone przez swe połączenie, wpadają do Jordanu przez góry i doliny". Dobra nowina jest więc głoszona zarówno Jordanowi, jak i Janowi na pustyni, który powtarzając ją sobie, pragnie swymi rękami ochrzcić Zbawiciela i daje swoje zaproszenie na zaślubiny świętej Oblubienicy:

„Dobra nowina Jordanowi, którego spływające wody ogrzane przez spalone skały Hermonu i Saniru zanurzają się głęboko u ujścia do morza, lecz powracają natychmiast, by w chrzcie dojrzeć Chrystusa. Dobra nowina wszystkim synom ludzkim, ukształtowanym z gliny, którzy widzieli dziś Ducha w postaci gołębicy.

Dobra nowina, ponieważ dzisiaj objawiła się tajemnica Trójcy Świętej. Śpiewajmy więc zawsze:

Chrystus jest błogosławiony na wieki”.

2. Najświętszej Maryi Pannie poświęcił Grzegorz specjalny, już wyżej wspomniany, panegiryk, napisany ok. 984 roku, zatytułowany od pierwszych jego słów „Koumark Khempitz” lub „Gumark Khmbits” (= wiele zastępów). Jego myślą przewodnią jest ukazana wieloaspektowo nauka o Wcieleniu, nie- 
rozerwalnie związana z Bogurodzicą. Daje to Grzegorzowi okazję, by opiewać w uroczystym tonie jej boskie macierzyństwo, które uważa za podstawę i źródło wszystkich innych jej pochwał - wyjątkowej godności i niezwykłej piękności. Poemat ten podobny jest w swej strukturze i treści, a nawet powtarzanych refrenach („Ciesz się” lub „Witaj”) do greckiego akatystu, śpiewanego w bizantyjskich kościołach. Hymn akatyst jest jednak ujęty w strofy (najczęściej 24) i od początku przeznaczony był do śpiewania, natomiast omawiany panegiryk stanowi długą podzieloną na 24 paragrafy prozaiczną mowę okolicznościową (miejscami rytmizowaną) z członami zdań monorymowanych, nawiązujących do zasad poetyckich obowiązujących w środowiskach perskich i arabskich. Sam zresztą Grzegorz pod koniec życia przyznał się w Księdze śpiewów żałobliwych do ulegania tym wpływom.

W uroczystym wstępie panegiryku Grzegorz zapowiada, że Dziewica Maryja, Matka Boga, zasługuje na pochwały wyjątkowe, które jednak trudno wypowiedzieć, dlatego nie mają odwagi czynić tego nawet chóry anielskie:
„Maryja przyjęła pod swym dachem uczynionym z ziemi Tego,
który jest niedostępny dla istot niebieskich; ona objęła
widzialnymi więzami swego ciała Tego, który jest
niewypowiedziany dla serafinów; Ona swoimi piersiami mlekiem
karmiła Tego, który żywi chóry aniołów. Jakiż więc śpiew
może być godzien, by błogosławić i czcić naczynie
Niewidzialnego i komnatę Wspaniałego, tabernakulum Pana,
namiot Bóstwa, kielich nieskazitelnej uczty, sanktuarium
niewinności, ołtarz czystości, prototyp dziewictwa, wzór
szczęśliwości, nierozerwalne ognisko nieziemskiego
Oblubieńca, mieszkanie, w którym znalazła upodobanie
niestworzona Boskość. Skoro więc ziemia została złączona z
niebem, aby nosić Boga-Zbawiciela, chóry niebieskie i chóry
ziemskie, złączmy się w jeden chór i śpiewajmy w uniesieniu".

Choć Grzegorz jest świadom, iż nie jest godny, by chwalić Maryję, to jednak nie może powstrzymać się od włączenia w śpiew ewangeliczny, ,aby wyśpiewać swoim głosem, o ile to możliwe, pragnienia swego serca" (§ 3). Śpiew kieruje bezpośrednio do Dziewicy, Matki Słowa Wcielonego, wyrażany w kolejnych paragrafach, z których sześć zaczyna się od słów „Raduj się”, a wszystkie rozpoczynają się lub kończą wezwaniem: „Matko Boża, Matko Pana, Matko Jezusowa, Matko Chrystusowa”. Tu właśnie widać naocznie podobieństwo do akatystu maryjnego, w którym większość wierszy zaczyna się od care (,witaj”), a co drugi kończy się wersetem: care, nmfh nmfeute („Witaj, dziewicza Oblubienico”) ${ }^{27}$.

Boskie macierzyństwo jest fundamentem nieporównywalnej wielkości Maryi i powodem do jej wychwalania, bo „Ona jest tylko pod Bogiem, a ponad

${ }^{27}$ Por. Hymn Akathistos, w: Muza chrześcijańska, III, OŻ 12, dz. cyt., s. 194-204. 
wszystkim tym, co nie jest Bogiem" (§ 4). To właśnie boskie macierzyństwo określa i finalizuje istnienie Maryi od pierwszego momentu zanurzenia jej w historię: „Zanim jeszcze Słowo było przez Ciebie zrodzone, byłaś zachowana nieskazitelną i bez jakiejkolwiek zmazy, otoczona i okryta skrzydłami aniołów” (§ 5)... „Byłaś wybraną bezgrzeszną córką pierwszej grzesznej kobiety” (§ 19). Mimo swej wielkości Maryja, według Grzegorza, jest „dobrocią bez skazy”, „Matką słodkiego wysłuchania”, ,nadzieją dla świata..., która jak źródło tryska słodyczą". Sam Bóg przygotował sobie tak wielką nieskazitelną Matkę dla swego Wcielonego Syna: „On zawarł dziś w Tobie wspaniałą wielkość, a ty poderwawszy swe loty osiągnęłaś niebiańskie wysokości jako ciało nieskłonne do zepsucia i rozkładu przez śmierć, która zawsze budzi lęk" (§7). Maryja mimo swej wielkiej godności jest pośredniczką między Bogiem a ludźmi, którym wyprasza wiele lask i dobrodziejstw:

„Tylko Ty, Panno błogosławiona, święta Theotokos, byłaś zdolna otrzymywać i rozdzielać tyle i tak wielkich dobrodziejstw, a przez czyste dziewictwo Ty byłaś kadzielnicą Najwyższej Istoty. Ponieważ jak mieszanina kadzidła, mirry, akacji i delikatnego zapachu, podsycająca ogień czystości, dałaś Bożemu powonieniu i wdziękowi Ojca przyjemną woń świętości. Ty, która jesteś, o Święta Matko Boga, czysta w swoim życiu, pełna dobroci, stała w łagodności, doskonała w cnocie i spływająca słodyczą.

Raduj się, o Maryjo, z całego serca, błogosławiona między niewiastami, Ty, któraś z dziewiczego i nietkniętego łona zrodziła Słowo, korzeń błogosławieństwa przeciw złu przekleństwa, syna radości Ojca Adama: To dlatego właśnie my, błogosławieni w twoim Synu Zbawicielu świata, składamy Ci dzięki i ogłaszamy błogosławioną, o Święta Theotokos! Tyś, na tej ziemi, żywiła i mlekiem macierzyńskim karmiła prawdziwego Syna Ojca światłości; Tyś troskliwie chroniła i strzegła jak pod skrzydłami Tego, który obejmuje wszystko. Swoim życiem ziemskim kierowałaś zgodnie z drogą życia niebiańskiego; i na podobieństwo ptaka w locie przemierzałaś swoje życie ziemskie; i wśród chórów aniołów okazałaś się strażniczką Bóstwa. Czczona przez nie, Ty na świetlistym obłoku dokonałaś swego wniebowstąpienia, a jako stworzenie uczynione z ziemi spoczywasz wśród chórów cherubinów; przez wszystkie urzekające piękności Raju zostałaś uznana za Gwiazdę Poranną i pod ludzką widzialną naturą ukryta w tajemnicy niewypowiedzianej laski” (§ 9-12). 
Grzegorz wreszcie wskazuje w panegiryku na szczególną pozycję Maryi w Kościele: „Przyklękając ofiarujemy Narodzonemu z Ciebie, podobna do nas, Maryjo, wszelką chwałę... w niewypowiedzianej budowli świętego Kościoła; o Najświętsza i Błogosławiona, do Ciebie kierujemy nasze błogosławieństwo” (§ 22). Swój poemat kończy wezwaniem do Maryi jako „Matki najbardziej zasłużonej dla założenia Kościoła” (\$ 24). Tajemnica Bogurodzicy jest więc wewnętrznie, w sposób istotny i całkowicie związana z tajemnicą Chrystusa i Kościoła, w którym odzwierciedla się i objawia wielkie znaczenie Maryi.

3. Treści maryjne, wyrażone obszernie w panegiryku, ujął Grzegorz syntetycznie w wierszowanej modlitwie, w 80 Pieśni (banie) Księgi śpiewów żałobliwych, w ,Słowie - jak sam w tytule zaznacza - do Matki Bożej z głębi serca płynącym"28. Świadom jest, że to już druga specjalna modlitwa maryjna, o której zaniesienie przed tron Boga pokornie prosi: „Przyjm zatem od sługi wiernego modlitwę tę błagalną / zanieś ją w darze do Boga / Pospołu z dawnymi słowy, / W których sławiłem Cię, Wielka"29. Pieśń ta, pisana miejscami rytmizowanym językiem, składa się z trzech części, poprzedzonych krótkim wezwaniem do Bogurodzicy, nawiązującym do atmosfery całej Księgi: „Z duszą całkiem strapioną ku Tobie się zwracam z błaganiem, Święta Bogurodzico!”

Już w części pierwszej rozpoczyna się pełna uczucia modlitwa Grzegorza, stanowiąca summę ówczesnej wschodniej grecko-syryjsko-armeńskiej mariologii, sławiąca wielkość Maryi za pomocą metafor i porównań oraz ukazująca w niej działanie Trójcy Świętej:

„Aniele spośród ludzi,

Cherubie w postaci człowieczej,

Królowo Niebieska!

Jako powietrze czysta,

Jak światłość nieskalana,

Jaśniejąca jak gwiazda poranna,

Wyniesiona ponad przybytek

Nietkniętej świątnicy najświętszej!

Tyś jest obietnica szczęsna,

Ogród Edenu żywy,

Nieśmiertelne drzewo żywota,

Strzeżone przez miecz ognisty!

Umocniona i osłonięta przez Ojca Najwyższego,

Oświecona i uświęcona przez Ducha Świętego,

Ozdobiona przez Syna, który począł się w Tobie

I uczynił Ciebie swym Tabernakulum,

${ }^{28}$ Por. Oeuvres complètes, Venise 1840, 252-258; przekład francuski J. Kéchichiana: SCh 78, 428-432; przekład polski A. Mandaliana: Księga śpiewów żałobliwych, 403-407.

${ }^{29}$ Księga śpiewów żałobliwych, 404. 
Dla Ojca - Jedynego,

Dla Cię - pierworodnego,

Syna z urodzenia i Pana przez stworzenie!

W czystości swej niesplamionej -

Tyś jest nieskażona dobroć,

W świętości swej nieskalanej -

Tyś orędowniczka troskliwa...,"30.

Tę tak scharakteryzowaną i uwielbioną Bogurodzicę i Matkę żyjących, prosi o wstawiennictwo i pomoc, by tu, na ziemi, mógł zawsze żyć dla Chrystusa:

„Abym za Twym dobrodziejstwem

I za wspomożeniem Twoim,

Znajdując schronienie i światłość

W najświętszym Twym Rodzicielstwie,

Żył zawsze dla Chrystusa,

Syna Twego i Pana!

Bądź mi przytomna na skrzydłach Twoich modłów

Ty, o której głoszą, żeś Matką żyjących" ${ }^{31}$.

W drugiej części Grzegorz najpierw powierza Maryi ostatnie chwile swego życia, a następnie prosi z ufnością o opiekę i pomoc w trudnościach doczesnych, o wyjednanie mu przebaczenia grzechów, a na koniec o objawienie się w nim jej czci, a w niej jego zbawienia. Każdą zaś prośbę kończy inną jej peryfrazą teologiczną:

„Abym odchodząc z tej ziemskiej doliny,

Szedł bez obawy ku siedliskom życia

Nam zgotowanym,

By lżej mi było przebyć kres żywota

Nieprawościami tak obarczonego.

W święto radości zmień dzień dusznej trwogi,

Lekarko boleści Ewy.

Bądź mą orędowniczką, proś za mną i błagaj:

Bo, jako wierzę w czystość Twą niewysłowioną,

Tako i wierzę, że Twe slowo będzie wysłuchane.

Opatrz mnie swymi łzami, bom w ciężkiej potrzebie,

O Ty, błogosławiona między niewiastami!

Zegnij kolano, by mi zjednać przebaczenie,

O Matko Boga!

\footnotetext{
${ }^{30}$ Tamże, 403-404.

31 Tamże, 404.
} 
Miej pieczę o mnie, bom wielce stroskany,

Przybytku Najwyższego!

Podaj mi rękę, bom w upadku,

O świątynio Niebieska!

Wysławiaj Syna swego w sobie,

By raczył sprawić we mnie boski

Cud odpuszczenia i miłości,

O Służebnico, Matko Boga!

Niechaj cześć Twoja objawia się we mnie,

A me zbawienie okazuje się w Tobie"32.

W trzeciej wreszcie, najdłuższej i chyba kompozycyjnie najpiękniejszej części Pieśni, poeta stwierdza, że wymienione wyżej prośby zostaną urzeczywistnione, jeżeli spełnią się pewne warunki, które wylicza, poprzedzając je na wzór litanii spójnikiem „Jeśli” i kończąc za każdym razem innym tytułem Maryi:

„Stanie się tak,

Jeśli Ty mię odnajdziesz,

Matko Boża;

Jeśli zmiłujesz się,

Panno Święta;

Jeśli odzyskasz mię, zatraconego,

Niepokalana;

Jeśli wysłuchasz mię, strwożonego,

Błogosławiona;

Jeśli wyróżnisz mię, zawstydzonego,

Błogości pełna;

Jeśli się wstawisz za mną, zrozpaczonym,

Dziewico przenajświętsza;

Jeśli mię, wygnanego, do łask swych przywrócisz,

Ty, którą Bóg ma w swej łasce;

Jeśli okażesz mi miłosierdzie,

Która uwalniasz z przeklęctwa;

Jeśli w rozterkach mych ześlesz mi pewność,

Ty, która nie znasz rozterki;

Jeśli uciszysz wzburzenie moje,

Ty, która znasz jeno pokój;

Jeśli mi, zbłąkanemu, ukażesz zbawienie,

Ty, któraś pełna chwały;

Jeśli ujmiesz się za mną,

Ty, która przeczysz śmierci;

32 Tamze, 404-405. 
Jeśli uciszysz mą gorycz,

Ty, któraś pełna słodyczy;

Jeśli zniesiesz przeszkody pomiędzy mną a Bogiem,

Ty, która godzisz, co sprzeczne;

Jeśli do dna zniweczysz nieprawości moje,

Ty, która niszczysz plugastwo;

Jeśli - na śmierć skazanemu - ześlesz mi ocalenie,

Światłości żywa;

Jeśli ukoisz żale głośnych lamentów moich,

Pocieszycielko strapionych;

Jeśli mi, zmiażdżonemu, przywrócisz zdrowie i siłę,

Balsamie żywota;

Jeśli wejrzysz na mnie i na zatracenie moje,

Ty, któraś pełna Ducha;

Jeśli w swym zmiłowaniu wyruszysz mi na spotkanie,

Ty, którą mamy w legacie! (J 19,27),33.

Ostatni fragment trzeciej części jest krótkim hymnem pochwalnym na cześć Maryi, Jezusa i całej Trójcy Świętej:

„Tyś bo jest sławiona jeno przez wargi szczęsne,

Nieskalane usta;

I gdyby mą duszę zrosiła

Jedna zaledwie kropla dziewiczego mleka Twojego,

Już by mi wystarczyło,

Aby przywrócić mi żywot.

Tyś bo Macierzą Pana najwyższego, Jezusa,

Stworzyciela ziemi i niebios,

Któraś Go była zrodziła sposobem niepojętym

W przyrodzeniu czlowieczym,

A w doskonałości Bożej;

Sławionego pospołu z Ojcem,

A jeszcze - z Duchem Świętym,

W istności swej niezbadanej

Zjednanego z naturą naszą!

On bo jest wszystkim we wszystkich,

Jeden w Trójcy Świętej,

Jemu - sława i chwała

Na wieki wieków.

Amen" 34 .

\footnotetext{
${ }^{33}$ Tamże, 405-407.

${ }^{34}$ Tamże, 407.
} 
4. Oprócz Słowa 80, także w kilku innych utworach Księgi śpiewów żałobliwych spotykamy drobne wzmianki o Maryi. Świadczą one o czci Grzegorza dla Bogurodzicy lub podkreślają jej pośrednictwo, o które prosi. Tak na przykład kończy się Słowo 26:

„Przed Tobą, ja, Matko Boża, niskie biję pokłony;

Bądź mi Orędowniczką! Żem duszy lichej niecnota -

Odpuść, Królowo Niebios, Uzdrowicielko żywota!

I niech Cię na wysokościach dosięgną z ugorów tych płonnych

Słodkie dymy kadzideł i olejków wonnych!”35

lub pełna prośby o wstawiennictwo wzmianka w Stowie 31:

„Panie, wraz z Krwią Twą świętą, napawającą grozą,

I z Matką Błogosławioną, która Cię z ciała zrodziła,

Niech się wstawią za nami” ${ }^{36}$

czy też początek Słowa 81:

„A wraz ze wstawiennictwem świętej Matki Bożej

Wysłuchaj, Panie, modłów niebiańskich Aniołów,

Świetlistych i nieśmiertelnych"37.

Oto krótki zarys wspaniałej mozaiki poezji maryjnej Grzegorza z Nareku, syntezy sui generis mistyki i teologii armeńskiej. Aby lepiej zrozumieć jego twórczość, trzeba go umieścić w gronie innych armeńskich doktorów, poetów, mistyków i pisarzy maryjnych, m.in. Nersesa Sznorhali (1102-1173), Nersesa z cylicyjskiego Lambron (1153-1198) ${ }^{38}$, Grzegorza z Tatew (13401410) i założyciela mechitarzystów św. Mechitara (1676-1749), którzy rozsławili mariologię armeńską, rozumianą i przeżywaną zawsze jako egzaltację Bogurodzicy w tajemnicy Chrystusa i Kościoła. Wyżej scharakteryzowane maryjne utwory Grzegorza, a zwłaszcza Panegiryk ku czci Bogurodzicy, zbliżone są do tzw. teologii monastycznej ${ }^{39}$, uprawianej w klasztorach na Zachodzie w wiekach od VI do XIII (w okresie między patrystyką a teologią scho-

${ }^{35}$ Tamże, 177.

36 Tamże, 206.

37 Tamże, 408.

${ }^{38}$ Por. J. Mécérian, La Vierge Marie dans la littérature médiévale de l'Arménie, s. 25-41 (Saint Nersès de Lampron).

39 M. Daniluk, Encyklopedia instytutów życia konsekrowanego i stowarzyszeń życia apostolskiego, Lublin 2000, 365-366. 
lastyczną), której odbiorcami były głównie środowiska mnisze. Do jej cech charakterystycznych należało odwoływanie się autora przede wszystkim do osobistego przeżycia prawd wiary, a nie do ich analiz filozoficzno-teolologicznych, a także posługiwanie się poetyckim językiem symboli, metafor, porównań, antytez i obrazów, aby przybliżyć człowiekowi te prawdy, wzbudzić w nim pragnienie Boga, pogłębić wiarę, pobudzić intelekt, ożywić nadzieję i miłość ${ }^{40}$. Teologii tej brak było jednak jasności i precyzji, właściwych późniejszej teologii scholastycznej. Jak bardzo twórczość Grzegorza z Nareku zbliżona jest nie tylko charakterem, lecz także poziomem do teologii monastycznej Zachodu, świadczy stwierdzenie J. Kéchichiana ${ }^{41}$, znawcy Grzegorza z Nareku, iż gdyby Panegiryk ku czci Bogurodzicy napisany został po łacinie, z pewnością przypisywany byłby św. Bernardowi z Clairvaux (zm. 1153), jednemu z najwybitniejszych przedstawicieli teologii monastycznej Zachodu.

Uznany za geniusza swoich czasów, jak podkreślił C. Kibarian, św. Grzegorz skupiał w sobie wszystko to, co duch armeński zdołał stworzyć od począt$\mathrm{ku}$ - wszystkie rozterki i niepokoje, jak również wszystkie ofiary i nadzieje swego narodu. Wierzył w nieprzemijającą moc swojej poezji, która ma wytyczać właściwą drogę wszystkim narodom, ma być przesłaniem dla przyszłych pokoleń, ma otwierać bramy ku wieczności ${ }^{42}$.

\section{MARIE DANS LES OEUVRES LITTÉRAIRES DE GRÉGOIRE DE NAREK}

(Résumé)

Dans cet article l'auteur après avoir caractérisé en général les oeuvres littéraires de Grégoire de Narek, l'un de plus célèbres poètes arméniens, vivant aux $\mathrm{X}^{\mathrm{e}}$ et $\mathrm{XI}^{\mathrm{e}}$ siècles, et après avoir esquisse l'ambiance intellectuelle du monastère à Narek, discute trois textes marials de Grégoire, c'est à dire: Le Panégiryque de la sainte Mère de Dieu, Le chant de Théophanie et 80 Parole du Livre de Lamentations. Dans ces oeuvres Grégoire approfondit divèrs aspects du mystère du Verbe Incarné et glorifie extraordinaire dignité, grandeur et beauté de la Vierge Marie.

${ }^{40}$ Por. V. Arak'elyan, Le langue et le style de Grégoire de Narek, Érévan 1975; J.P. Mahé, Echos mythologiques et poésie orale dans l'oeuvre de Grigor Narekac'i, REArm NS 17 (1983) 249 278; A. Łazinean, Grigor Narekac'i et son art poétique, Antilias 1995 (po armeńsku).

${ }^{41}$ Por. Introduction, w: Grégoire de Narek, Le livre de prières, s. 37.

${ }^{42}$ Por. C. Kibarian, Histoire de la littérature arménienne, t. I, Des origines jusqu'à 1300, Venise 1944. 